IRSH 49 (2004), Supplement, pp. I 59-I77 DOI: I0.I0I7/S002085900400I683

(C) 2004 Internationaal Instituut voor Sociale Geschiedenis

\title{
Framing Jihad: Intramovement Framing Contests and al-Qaeda’s Struggle for Sacred Authority
}

\author{
QUINTAN WIKTOROWICZ
}

Summary: This article emphasizes the credibility of popular intellectuals as a point of contention in framing contests. A movement group - a faction, clique, submovement, network cluster, organization, etc. - asserts its authority to speak on behalf of an issue or constituency by emphasizing the perceived knowledge, character, and logic of its popular intellectuals while attacking those of rivals. Four basic framing strategies relevant to the credibility of popular intellectuals are identified: (I) vilification - demonizing competing popular intellectuals; (2) exaltation - praising ingroup popular intellectuals; (3) credentialing - emphasizing the expertise of the ingroup intellectuals; and (4) decredentialing - raising questions about the expertise of rivals. Al-Qaeda's intramovement framing struggle with nonviolent Islamic fundamentalists over the permissibility of violence is used as a case study. In an attempt to assert its right to sacred authority, the movement portrays scholars who support its jihad as logical, religious experts of good repute while characterizing opposing clerical popular intellectuals as emotional, corrupt, naïve, and ill-informed about politics.

Over the past several decades, a dense ideological network of Islamic fundamentalists known as salafis has expanded dramatically to become one of the largest Islamist movements in the Muslim World. The term, salafi, is derived from the Arabic salaf, which means "to precede", and refers to the companions of the Prophet Mohammed. Because the salaf learned about Islam directly from the messenger of God, their example is an important illustration of piety and unadulterated religious practice. Salafis argue that centuries of syncretic cultural and popular religious rituals and interpretations have distorted the purity of the message of God, and that only by returning to the example of the Prophet and his companions can Muslims reach Paradise in the hereafter. The label, salafi, is thus used to connote "proper" religious adherence and moral legitimacy, implying that alternative understandings are corrupt deviations from the straight path of Islam. $^{\mathrm{I}}$

I. For more details about the salafi ideology, see Quintan Wiktorowicz, The Management of Islamic Activism: Salafis, the Muslim Brotherbood, and State Power in Jordan (Albany, NY, 200I), ch. 4 . 
The nodes of the network are constituted by religious scholars, who interpret sacred texts and outline the obligations of Islam in the modern context. These scholars are "popular intellectuals", in the sense that they provide interpretations of Islam and frames that guide salafi activism and collective action, which are seen as necessary to fulfill duties to God. The decentralized nature of religious authority in the Muslim world, however, means that no single individual or group of scholars enjoys theological hegemony or dictates how all salafis engage in collective action. Although salafis are united in their methodological approach to religious interpretation, which emphasizes the prophetic model and the paradigm of the salaf, the fragmentation of religious authority has engendered schisms within the salafi community, particularly over the issue of violence.

In the wake of the Soviet invasion of Afghanistan in 1979, there was initial agreement that violence in defense of an occupied Muslim country is an individual obligation (fard 'ayn), incumbent upon all able Muslims through verbal, financial, or physical support. Even after the Soviet withdrawal, there was agreement that violence was necessary to support Muslims in places like Bosnia and the Palestinian territories. This consensus, however, began to erode as "Arab Afghans" returned from the front and organized violence in their home states. Salafi jibadis continued to support the use of violence while "reformists" emphasized the necessity of individual spiritual transformation, propagation, and advice to the rulers and umma (Muslim community). Al-Qaeda is part of the jibadi faction. ${ }^{2}$

During the I980s and I990s as al-Qaeda developed, the initial debate between violent and non-violent salafis was over takfir - declaring a Muslim an apostate. The central axis of divergence was over whether one could judge a ruler in the Muslim world an apostate according to his actions. ${ }^{3}$ Nonviolent groups argued that one can never know with certainty what is in an individual's heart, and that, so long as a ruler has a "mustard seed of iman [belief]", Muslims cannot rebel. The jihadi salafis, on the other hand, argued that the oneness of God (tawhid) demands that Muslims follow Islam in both belief and action. In other words, an unIslamic action is just as revealing as an un-Islamic belief. As a result, the jihadis charged the Saudis and other regimes in the Muslim world with apostasy and called for a jihad to remove them from power.

In the late I990s, although this debate continued, it became less relevant to Islamist struggles on the ground, as jibadis faced defeat and marginalization throughout the Middle East. This was particularly the case in the

2. See idem, "The New Global Threat: Transnational Salafis and Jihad", Middle East Policy, 8 (200I), pp. I $8-38$.

3. This brief history is taken from Quintan Wiktorowicz and John Kaltner, "Killing in the Name of Islam: Al-Qaeda's Justification for September I I", Middle East Policy, I० (2003), pp. $76-92$. 
largest Islamist insurgencies in Egypt and Algeria. ${ }^{4}$ In Egypt, leaders from both the Islamic Group and Islamic Jihad declared ceasefires and the violence came to a dramatic end. Elements from within the Islamic Group went so far as to issue a public apology for the violence. In a move that epitomized the recasting of the jihadis, a number of Islamists from both groups attempted to establish political parties (the Shari'a and Islah parties), though the regime rejected the requests for permits. Violent jibadi dissidents found themselves marginalized, and many left for Pakistan and Afghanistan to work directly with al-Qaeda.

In Algeria, a similar process occurred. The regime's decision to cancel elections in I992, as Islamists were poised to control parliament, sparked an insurgency that has claimed more than I50,000 lives. Early in the conflict, the jibadi salafis united under the banner of the Armed Islamic Group (GIA) and attacked government officials and soldiers. In 1996, however, the GIA launched a series of civilian massacres that undermined the unity of the Islamist opposition: a number of salafi rebel groups (as well as non-salafi groups such as the Islamic Salvation Army) condemned the atrocities and issued unilateral ceasefires. The regime, in turn, responded to the ceasefires by using an amnesty program to reintegrate former Islamist fighters into society. Although a number of radical groups continue to operate, the violence has dropped substantially since the late I990s. As a result, many Algerian jibadi salafis placed their networks, resources, and personnel at the service of al-Qaeda. ${ }^{5}$

For nonviolent salafis, these defeats made it clear that the jihadi vision to unseat incumbent Muslim regimes was at an end (at least in the short term), and so the issue of takfir became less prominent in debates over violence. Instead, the focus shifted to al-Qaeda's war against the US and its allies. In general, salafis share the same diagnostic frame: the US is waging a war of aggression against Islam and is responsible for many of the problems in the Muslim world. Differences emerge, however, over the proper response and course of action. Jihadis, once again, call for violence while the nonviolent salafis promote reform. Each side proffers an assortment of fatwas (religious jurisprudential opinions) and copious religious evidence to support its position.

This dispute is a "framing contest" 6 in which each contender not only asserts particular religious interpretations but also claims "sacred authority" - the right to interpret Islam and religious symbols on behalf of the

4. See, for example, Fawaz Gerges, "The Decline of Revolutionary Islam in Algeria and Egypt", Survival, 4I (1999), pp. II3-I25.

5. See Quintan Wiktorowicz, "The GIA and GSPC in Algeria”, in Magnus Ranstorp (ed.), In the Service of al-Qaeda: Radical Islamic Movements (New York, forthcoming).

6. Charlotte Ryan, Prime Time Activism: Media Strategies for Grassroots Organizing (Boston, MA, I99I). 
Muslim community. ${ }^{7}$ The jihadis and reformists operate in a competitive religious marketplace of ideas, and therefore must offer religious interpretations or "products" that can effectively tap into audience predispositions and personal understandings about religion and its application in the modern world. The target audience of framing efforts, however, is not an assortment of religious scholars capable of adjudicating complex theological debates. The vast majority of Muslims find it extremely difficult to weigh the considerable religious evidence marshaled by both sides of the framing contest. Under such circumstances, frame resonance has little to do with the theological arguments themselves, or the supportive evidence. Instead, audiences use the reputation and authority of scholars as heuristic devices to ascertain authenticity. As a result, both the jibadis and the reformists assert the legitimacy of their scholars and concomitant authority to issue fatwas.

Using interviews, fatwas, and speeches by Osama Bin Laden, and other al-Qaeda representatives, this article examines the framing strategies used by al-Qaeda to assert its right to sacred authority and promote jihad. ${ }^{8}$ Rather than focusing on popular intellectuals as ideological producers or frame articulators, I emphasize the credibility of popular intellectuals as a point of struggle. Four basic framing strategies relevant to the credibility of popular intellectuals are identified: (I) vilification - demonizing competing popular intellectuals; (2) exaltation - praising ingroup popular intellectuals; (3) credentialing - emphasizing the expertise of the ingroup intellectuals; and (4) decredentialing - raising questions about the expertise of rivals. These strategies are designed to assert a group's authority in framing contests by emphasizing the perceived knowledge, character, and logic of its popular intellectuals while attacking those of rivals.

\section{INTRA-MOVEMENT FRAMING CONTESTS AND CREDIBILITY}

Social movements are not monolithic entities. They are represented by myriad actors with oftentimes competing tactics, strategies, and goals. As Mayer Zald and John McCarthy argue:

7. Dale F. Eickelman and James Piscatori, Muslim Politics (Princeton, NJ, 1996).

8. This article primarily draws from two sources. First, it uses interviews I conducted between 1996 and 1997 with jihadi and reformist salafis in Jordan, which represents an intellectual hub for salafi scholars from both groups. Second, it uses the most prominent public statements issued by al-Qaeda before and after the September i I attacks. Public statements are seen as appropriate sources since they are explicit modes for disseminating frames intended for popular consumption. 
Whether we study revolutionary movements, broad or narrow social reform movements, or religious movements, we find a variety of SMOs [social movement organizations] or groups, linked to various segments of supporting constituencies (both institutional and individual), competing among themselves for resources and symbolic leadership, sharing facilities and resources at other times, developing stable and differentiated functions, occasionally merging into ad hoc coalitions, and occasionally engaging in all-out war against each other. ${ }^{9}$

Robert Benford and others echo this assessment: "SMOs compete with one another for instrumental resources such as money, constituents, and third party support, as well as for symbolic goods such as turf, status, and prestige". ${ }^{\circ}$

Intramovement conflict is particularly common in framing, so much so that William Gamson and David Meyer encourage us, "to think of framing as an internal process of contention within movements with different actors taking different positions". ${ }^{11}$ Although movements may enjoy "cognitive closure", whereby debate about core issues and beliefs is limited, ${ }^{12}$ there are frequent disagreements about specifics and plans of action, creating diversity and multiple voices that claim to represent a movement. ${ }^{13}$ Groups often diverge in terms of diagnosis, prognostication, the best way to mobilize support, and identity. These struggles are contests to influence the direction of the movement: how resources should be used, the proper construction and dissemination of symbols and discourses, acceptable alliances, etc. An intra-movement framing contest is, in short, a struggle to assert authority.

Within this struggle, credibility is central. ${ }^{\mathrm{I}} \mathrm{A}$ messenger of disrepute will undermine the potential frame resonance of a message by leading audiences to question the source of information and argument. Those with

9. Mayer N. Zald and John D. McCarthy, "Social Movement Industries: Competition and Conflict Among SMOs", in idem (eds), Social Movements in an Organizational Society (New Brunswick, NJ, i987), p. I6r.

ı०. Robert D. Benford, "Frame Disputes within the Nuclear Disarmament Movement", Social Forces, 7I (1993), p. 68I; idem and Louis Zurcher, "Instrumental and Symbolic Competition among Social Movement Organizations", in Sam Marullo and John Lofland (eds), Peace Action in the Eighties (New Brunswick, NJ, I990), pp. I25-I39.

I I. William A. Gamson and David S. Meyer, "Framing Political Opportunity", in Doug McAdam, John D. McCarthy, and Mayer N. Zald (eds), Comparative Perspectives on Social Movements: Political Opportunities, Mobilizing Structures, and Cultural Framings (Cambridge, I996), p. 283.

I 2. Luther P. Gerlach and Virginia H. Hine, People, Power, Change: Movements of Social Transformation (Indianapolis, IN, I970), p. I6r.

I 3. Benford, "Frame Disputes within the Nuclear Disarmament Movement", pp. 677-70I; Benford and Zurcher, "Instrumental and Symbolic Competition among Social Movement Organizations”.

I4. See Benford, "Frame Disputes within the Nuclear Disarmament Movement", pp. 692-693; Robert D. Benford and David A. Snow, "Framing Processes and Social Movements: An Overview and Assessment", Annual Review of Sociology, 26 (2000), pp. 620-62 I. 
sufficient reputations, in contrast, will elicit trust and enhance prospects for successful message dissemination. The credibility of the messenger is a necessary prerequisite for frame alignment. Each group must therefore demonstrate that it has the right, authority, and credibility to speak on behalf of the movement. Where popular intellectuals are involved (either directly or indirectly), their credibility is of particular importance since they are the "experts", "thinkers", and "ideologues" of the movement.

Although research on framing contests mostly deals with movementcountermovement interactions, recent work has identified several strategies relevant to the credibility of popular intellectuals in intramovement framing contests. ${ }^{\text {IS }}$ These strategies can generally be broken into two categories: crediting and discrediting. The former represents attempts to emphasize the legitimacy of a movement group's institutions, efforts, and popular intellectuals by highlighting knowledge proficiency, sincerity, and other positive attributes that demonstrate the right and ability of the group to speak on behalf of a cause. This is primarily an inward-focused approach. Discrediting, on the other hand, is an outward-directed attack against the reputation of intramovement rivals and opposing popular intellectuals to undermine and weaken the authority of competitors. Movements typically use a combination of both approaches. The following briefly outlines some of the most common framing strategies relevant to credibility issues.

\section{Vilification and exaltation}

Movement groups often use framing to distinguish themselves from other groups, including other protagonists, antagonists, and neutral bystanders. ${ }^{16}$ In a sense, a group must justify its raison d'être by demonstrating its

I 5. Marsha L. Vanderford, "Vilification and Social Movements: A Case Study of Pro-Life and Pro-Choice Rhetoric”, Quarterly Journal of Speech, 75 (1989), pp. I66-182; Scott A. Hunt, Robert D. Benford, and David A. Snow, "Identity Fields: Framing Processes and the Construction of Movement Identities", in Enrique Laraña, Hank Johnston, and Joseph R. Gusfield (eds), New Social Movements: From Ideology to Identity (Philadelphia, PA, I994), pp. I85-208; Patrick G. Coy and Lynne Woehrle, "Constructing Identity and Oppositional Knowledge: The Framing Practices of Peace Movement Organizations during the Persian Gulf War", Sociological Spectrum, I6 (1996), pp. 287-327, as cited in Benford and Snow, "Framing Processes and Social Movements", p. 62 I; Ira Silver, "Constructing 'Social Change' through Philanthropy: Boundary Framing and the Articulation of Vocabularies of Motives for Social Movement Participation", Sociological Inquiry, 67 (1997), pp. 488-503; Dawn McCaffrey and Jennifer Keys, "Competitive Frame Processes in the Abortion Debate: Polarization-Vilification, Frame Saving, and Frame Debunking”, The Sociological Quarterly, 4I (2000), pp. 4 I-6I; Robert D. Benford and Scott A. Hunt, "Interactional Dynamics in Public Problems Marketplaces: Movements and the Counterframing and Reframing of Public Problems", in James Holstein and Gale Miller (eds), Challenges and Choices: Constructionist Perspectives on Social Problems (New York, 2003), pp. I 53-I 86.

I6. Hunt et al.,"Identity Fields". 
unique position and relevance in a competitive identity environment. This is particularly important in cases of intramovement competition characterized by struggles over symbolic and instrumental resources. Under such circumstances, asserting a unique identity can help secure necessary resources, even if these come from small groups of supporters. Groups thus engage in both extra- and intramovement "boundary framing". ${ }^{17}$ In boundary framing, strategies of polarization accentuate differences and draw sharp ingroup/outgroup distinctions. ${ }^{18}$ This often generates stark bifurcations between real movement activists and pretenders, the true believers and the hypocrites, the misguided and the informed, good and evil. In extreme cases, the world is simply divided into two camps in Manichean fashion: those aligned with the movement group and those against it. Competitors are frequently lumped into a generic "other" category.

This polarization is typically accompanied by strategies of vilification. ${ }^{19}$ The "other" category is laden with negative characteristics and an assortment of claims intended to impugn the reputation of competitors. Vilification includes tactics such as name-calling - the use of labels to connect an individual or group to a negative symbol, event, or phenomenon, often in an attempt to produce visceral responses that erode the target's ability to assert credibility. Name-calling can challenge the intentions of a group, ridicule its values and activities, or obfuscate its agenda and goals. Examples include use of the terms "femi-nazi", "bleeding-heart liberals", and "tree-huggers".

Name-calling can have a powerful effect by packaging an assortment of wide-ranging connotations in a single label. In some instances, bystanders may reject a movement or group based on responses to the label rather than the message. Successful use of name-calling may even force groups to abandon previously accepted labels to avoid the negative associations. Vilification also includes character assassination, various forms of maligning, ${ }^{20}$ and the purposeful misrepresentation of a group's views and efforts through such techniques as caricatures, extreme cases, stereotypes, and guilt by association..$^{21} \mathrm{~A}$ common counter-frame leveled at the nuclear-freeze and peace movements, for example, accused activists with aiding the "enemy," whether intentionally or unintentionally. ${ }^{22}$ Other movements have been maligned as corrupt, hypocritical, or tools of nefarious interests.

17. Ibid.; Silver, "Constructing 'Social Change' through Philanthropy”.

I8. McCaffrey and Keys, "Competitive Frame Processes in the Abortion Debate".

19. Vanderford, "Vilification and Social Movements"; McCaffrey and Keys, "Competitive Frame Processes".

20. Benford and Hunt, "Interactional Dynamics in Public Problems Marketplaces".

2 I. Ryan, Prime Time Activism, p. 85.

22. Benford and Hunt, "Interactional Dynamics in Public Problems Marketplaces", pp. I66I67. 
Polarization is also typically accompanied by exaltation, the polar reflection of vilification. This strategy emphasizes the positive attributes of the ingroup, which is characterized as pure of heart, selfless, and independent. The claim is that the group is a vanguard representing the better interests of the community through sacrifice and effort. By extension, ingroup popular intellectuals are credible and authoritative, since they possess all the positive attributes of the group.

Where popular intellectuals are important for the construction of frames, they are often targets of vilification and exaltation. ${ }^{23}$ If the credibility of a frame relies upon the credibility of a popular intellectual, attacks against the latter will help weaken the viability of the former. This is particularly the case where complex issues are involved. As Robert Furtell argues, where social movement issues are of a technical nature (as in religious debates over violence), "Expert authority may powerfully shape the contours of framing activities. The language of science and expertise can stall efforts of nonexperts to understand what is going on. Lay citizens have to place a great deal of faith in the authority and judgments of experts." 24 This faith in experts is, in turn, contingent upon the reputations of the vying authorities. In Madison County, Kentucky, for example, the "Not in My Back Yard" (NIMBY) movement attempted to stop a US army plan to incinerate chemical weapons at a local site. The movement's framing efforts initially succeeded in mobilizing local opposition, in part, because army experts made errors in presenting their case, thereby compromising the credibility of the government's technical information and interpretation. ${ }^{25}$

\section{Credentialing and decredentialing}

In addition to issues of character and trustworthiness, there is also a question of whether the popular intellectuals have credible expertise. Although there is little research to date on the issue of expertise and frame resonance, Robert Benford and David Snow argue that "Hypothetically, the greater the status and/or perceived expertise of the frame articulator and/or the organization they represent from the vantage point of potential adherents and constituents, the more plausible and resonant the framings of claims." ${ }^{26}$ In other words, those who speak on behalf of the movement

23. Popular intellectuals also produce vilification and exaltation frames. They may, however, consciously avoid becoming personally embroiled in frame disputes to protect their image as dispassionate experts. Under these conditions, others in the movement may be responsible for developing and articulating the frames.

24. Robert Furtell, "Framing Processes, Cognitive Liberation, and NIMBY Protest in the US Chemical-Weapons Disposal Conflict”, Sociological Inquiry, 73 (2003), p. 380.

25. Ibid.

26. Benford and Snow, "Framing Processes and Social Movements", p. 62 I. 
should seem as though they know what they are talking about. Framing efforts that focus on establishing and advertising expertise can be thought of as a strategy of credentialing, ${ }^{27}$ which is frequently accompanied by attacks against the expertise of competitors, or decredentialing.

Although research tends to focus on the expertise of active frame articulators, it is also important to consider the credibility of popular intellectuals who are not involved in framing efforts but whose arguments and ideas are incorporated into movement frames. There are instances where movements "adopt" popular intellectuals and incorporate their work into movement frames. This allows movements to utilize popular intellectuals across time and space, sometimes without the acquiescence of the appropriated individuals. Marx, Locke, Gandhi, and Martin Luther King, for example, are utilized by an assortment of movements today, oftentimes in quite unique ways. And Muslim activists incorporate Islamic scholars from throughout the Muslim world into local frames. In some cases, movement antagonists may adopt the same popular intellectuals to make distinct and contrary arguments, demonstrating the elasticity of borrowed ideas.

\section{Criteria of credibility}

The different framing strategies related to credibility attempt to emphasize criteria for ingroup intellectuals while depicting opponents as devoid of the characteristics necessary for authority. The particulars of these strategies, however, depend upon the specific criteria for expertise in a given movement, community, culture, and/or society. In short, it depends upon what the popular intellectual or the frame is addressing and the given context and audience.

Despite these differences, there are several plausible generic criteria of credibility. First, the popular intellectual must seem knowledgeable. In most cases, he/she must not only understand the movement values, but also the context of activism. Scholars have argued for the importance of empirical credibility for frame resonance, ${ }^{28}$ and one could argue that popular intellectuals need to appear grounded in reality as well. Are they realistic in their assessment of the context? Do they seem to understand the realities of activism? For example, counter-frames may attempt to undermine competing groups by arguing that their popular intellectuals are "all heart and no head", or "well meaning but naïve". ${ }^{29}$ These buzz phrases connote well-intentioned intellectuals who simply do not understand how things get done in the real world, captives of an ivory tower

27. Coy and Woehrle, "Constructing Identity and Oppositional Knowledge".

28. David Snow, and Robert D. Benford, "Ideology, Frame Resonance and Participant Mobilization", International Journal of Social Movement Research, I (1988), p. 208; Benford and Snow, "Framing Processes and Social Movements", pp. 619-620.

29. Benford and Hunt, "Interactional Dynamics", p. I66. 
impervious to reality. It is important to note that "reality" is a subjective construct and as such means different things for different groups.

Second, credibility likely depends upon the perceived character of the popular intellectual. Charges of corruption or deviance undermine the reputation and status of the intellectual by calling into question his/her moral certitude. Is the popular intellectual working for the best interests of the movement because he/she believes in the cause? Or does he/she have ulterior motives? Is the individual doing what he/she thinks is right or is he/she being directed by forces outside the movement or group (particularly "the enemy")? Such questions are related to issues of trust and sincerity and can be tied into perceptions about the ethics of the intellectual.

Third, popular intellectuals should appear logical. Although some social movements might question issues of logic and reason as andocentric or positivistic constructs, most value rational thought and argument. Popular intellectuals who are inconsistent, for example, might appear wavering, illinformed, or hypocritical.

In the following case study, I show how al-Qaeda uses the framing strategies outlined above to address issues of knowledge, character, and logic. The movement has attempted to assert hegemony over sacred authority by endowing its own religious scholars with the necessary criteria of credibility while attacking the reputations of opposing clerical popular intellectuals within the salafi community. Because of the importance of scholarly reputation for the resonance of fatwas, issues of credibility are central to the jibadi-reformist framing contest.

\section{AL-QAEDA AND THE STRUGGLE FOR SACRED AUTHORITY}

Sacred authority in the Muslim world is the decentralized, informal recognition of the expertise and character of religious scholars. There is no formal hierarchy capable of establishing a clerical caste akin to the Catholic Church (with the exception of the Shiite community). Instead, authority hinges upon reputation, which is developed during years of interaction with the Muslim community through religious lessons, rulings, publications, and pronouncements. The title alim (religious scholar, pl. ulama) is not a formal designation or appointment; it is informal acknowledgment of expertise. This informality means that there is no enforcement instrument when a scholar issues a fatwa. Nor is there an adjudication mechanism to determine "right" and "wrong" religious legal rulings. As a result, audiences rely extensively upon the perceived expertise and character of a scholar to determine whether the interpretation is accurate, legitimate, and worthy of being followed.

Both the jibadi and reformist salafis recognize the essential role of 
scholars as intermediaries between the sacred texts and everyday religious rituals and practices. In his "Address to the Ummah on the Anniversary of the Crusader War", for example, Bin Laden emphasizes the importance of the scholars:

While the Ummah has its collectivist duties, and a common role which it has to carry out collectively, there are groups who have a specific role which they have to take care of in a special manner. In the lead of these groups is the group of the Islamic scholars and callers to Allah, who are the heirs of the prophets, who are the holders of the knowledge trust, and the obligation to the duty of calling to Allah and the duty of announcing him. And that's why Allah had raised their status and heightened their significance and importance, when He said, "Allah will exalt in degree those of you who believe, and those who have been granted knowledge" (Quran, Al-Mujadala, verse i r). ${ }^{30}$

Reformist salafis repeat these sentiments and argue that "The source for mankind's rectification is through knowledge." ${ }^{3}$ Both sides recognize the scholars as the inheritors of the prophetic message, intellectually equipped to interpret the immutable sources of Islam and the paradigm of the salaf in light of the changing conditions of the temporal world. A theological argument about jibad therefore requires the support of scholars for legitimation.

Because both sides mobilize scholarly opinions and present religious evidence, the credibility of the clerical popular intellectual is paramount. Most Muslims simply do not have a command of Islam sufficient to adjudicate the different arguments; each sounds plausible, given the weight of evidence marshaled to either perspective. As a result, framing strategies are used to influence audience evaluations about the knowledge, character, and logic of the competing scholars.

\section{Knowledge}

Most important reformist scholars hold Ph.D.s in the Islamic sciences from established Islamic universities, particularly in Saudi Arabia. They include a long list of luminaries with solid international reputations for knowledge, and their fatwas have wide-reaching global import. Reformist control of the state-sanctioned religious institutions in Saudi Arabia has provided resources and platforms to reinforce this impact and perceptions about religious authority. Given the pedigree and standing of the reformist scholars, decredentialing through attacks against the religious expertise of the reformist popular intellectuals is rather limited. While the jibadis have

30. Osama Bin Laden, "Address to the Ummah on the Anniversary of the Crusader War Jihad", available at www.jihadunspun.com. Accessed I November 2002.

3I. "Respecting the Status of Scholars", Al-Asaalah Magazine, available at: www.al-manhaj. com/articles/knowledge/Kio02.html. Accessed 9 October $200 \mathrm{I}$. 
argued that particular reformist scholars are weak in specific areas of the Islamic sciences, they have found it difficult to assail the expertise of the reformists as a collectivity.

Instead, decredentialing has focused upon nonreligious knowledge. Reformists might be credited with their thorough religious training, but jibadis frequently argue that they have little understanding about context. In other words, reformists are portrayed as incapable of applying the immutable religious sources to dynamic contemporary conditions because they have a limited grasp of the latter. They are framed as ignorant or naïve when it comes to politics, and therefore incapable of issuing well informed, relevant fatwas.

Jihadis, for example, point to Mohammed Nasir al-Din al-Albani (d. 1999) as a case in point. ${ }^{32}$ Al-Albani's religious knowledge is unassailable. He trained not only some of the most influential reformist scholars of the contemporary period, but several well known jihadi scholars as well. Jihadis point to several of al-Albani's fatwas, however, as evidence that he did not quite grasp the context of his religious rulings. One related to the Israeli-Palestinian conflict called for Palestinians to leave the occupied territories. Jibadis argue that this fatwa did not take into account the demographic struggle on the ground, and that its implementation would have, in effect, ceded control of the disputed territories to Israel. This decredentialing strategy was severe enough to elicit a response from al-Albani, who argued for a division of labor between the specialists of religious knowledge and current affairs experts. ${ }^{33}$

Al-Qaeda also argues that the reformist scholars issued ill-informed fatwas because they were deceived by the Saudi regime. In his 1996 "Declaration of War", for example, Bin Laden pays homage to the "honorable ulama and scholars", but argues that they were duped into issuing a fatwa supporting the presence of American troops in Saudi Arabia during the first Gulf War:

When the Islamic world resented the arrival of the crusader forces to the land of the two Holy Places, the king told lies to the Ulamah (who issued fatwas about the arrival of the Americans) and to the gathering of the Islamic leaders at the conference of Rabitah which was held in the Holy City of Makka. The king said that: "the issue is simple, the American and the alliance forces will leave the area in a few months". 34

A strategy of decredentialing, however, is dangerous for the jibadis since they suffer from a "reputation deficit". Al-Qaeda's "scholars" have limited

32. Author's interviews with jihadi salafis in Jordan, I996-1997.

33. Muhammad Naasir ud-Deen al-Albaanee, Abu Talhah Dawud ibn Ronald Burbank (tr.), The Knowledge of Current Affairs (Ipswich, 1994).

34. Osama Bin Laden, "Declaration of War against the Americans Occupying the Land of the Two Holy Places", published in al-Quds al-Arabi (London), 8 August 1996. 
student followings and reputations. Many are what Olivier Roy terms "new Islamist intellectuals" - well educated individuals from Westernstyle schools who turned to religion after facing blocked social mobility in their professions. 35 These "new intellectuals" rarely attended institutes of higher religious education, instead preferring either self-education or informal study circles and lessons. Certainly there are a few exceptions to this, including a small handful of Saudi clerics and Omar Abdul Rahman, a graduate of al-Azhar University in Cairo who was sentenced to life imprisonment in the US for conspiracy to wage terrorism; and the jibadis do try to emphasize the formal credentials of supporting scholars where possible. ${ }^{36}$ But credentialing efforts are rather limited and more often draw upon famous salafi scholars across time, such as Ibn Taymiyya. Any effort to challenge the credentials of reformists opens the possibility that audiences will judge al-Qaeda according to the same criteria. Even if an audience accepts the jihadi argument that the reformists are ignorant or naïve about current affairs, they may ask whether the jibadis are ignorant or naïve about the Islamic sciences. As a result, credentialing and decredentialing that target the criterion of knowledge are rather limited.

\section{Character}

Perhaps to a large extent due to its reputation deficit, al-Qaeda predominantly relies upon the strategies of vilification and exaltation to present itself as a moral authority, while discrediting its detractors as unworthy of the sacred trust of religious interpretation. Virtually every al-Qaeda statement that addresses issues of credibility and sacred authority includes attacks against the character of opposing ulama, and represents al-Qaeda as a sacrificing, sincere vanguard following a moral charge to defend the Muslim community against aggression.

Al-Qaeda's most important framing strategy is vilification. Because it cannot assail the expertise of the reformists, it must impugn and malign character and intent. If audiences distrust the character of the messenger, they will likely question the religious interpretation and whether it is motivated by a real devotion to God or selfish interests that corrupt religious rulings. A ubiquitous tactic is use of the term ulama al-sulta ("the scholars of power"). The term is laden with negative connotations, implying an insidious relationship with regimes and authority structures that undermines the independence and legitimacy of Islamic interpretation. It is typically surrounded by a barrage of other disparaging terms, such as "palace lackeys", "the corrupt ulama", and "the ulama who flatter

35. Olivier Roy, The Failure of Political Islam, Carol Volk (tr.) (Cambridge, 1994).

36. See, for example, Islamic Group military commander and al-Qaeda leader, Rifa'ey Ahmad Taha's interview in Nida'ul Islam (April-May 1997). 
[those in power]". Even more damning, al-Qaeda ties these scholars directly to the Ministry of the Interior in Saudi Arabia, responsible for maintaining internal security: "Sometimes officials from the Ministry of the Interior, who are also graduates of the colleges of the Shari'ah, are leashed out to mislead and confuse the nation and the Ummah (by wrong fatwas) and to circulate false information about the movement [al-Qaeda and jibadis]." 37 For al-Qaeda, this means that these scholars "speak in their masters' languages and in the concepts of the enemy of the umma". ${ }^{8}$

The potency of this framing strategy derives from increased government usurpation of institutions responsible for producing religious interpretations. Concerned about legitimacy and religious opposition, regimes throughout the Muslim world have attempted to centralize religious authority under state control. Mosques, religious institutes of higher learning, committees responsible for issuing fatwas, and other vehicles of religious meaning have been bureaucratized and linked to the state. Religious functionaries, including many of the ulama, are now dependent upon the state for their salaries and positions. ${ }^{39}$ Serious divergences from government interpretations of Islam can incur severe reprimands, dismissal (and thus loss of income), and even imprisonment. James Piscatori has gone so far as to argue that the ulama in Saudi Arabia, the center of the salafi movement, have become "agents of the state"..$^{\circ}$

While this may prevent broad dissemination of radical ideologies, it concurrently undermines the legitimacy of the ulama itself. Even supporters of the reformist vision admit that state controls create at least the appearance that the reformist scholars are no more than civil servants charged with protecting regime interests. The jibadis seize upon this widely-held perception and attack the intentions of those who issue fatwas against violence. Bin Laden, for example, observes that:

The offices of the Clerics Authority [in Saudi Arabia] are adjacent to the royal palace [...]. In such a situation [when even the offices are linked], is it reasonable to ask a civil servant [for a fatwa], who receives his salary from the king? What is the ruling regarding the king, and should the king be regarded as supporting infidels? ${ }^{\mathrm{I}}$

37. Bin Laden, "Declaration of War".

38. Al-Qaeda, "A Statement from Qa'idat al-Jihad Regarding the Mandates of the Heroes and the Legality of the Operations in New York and Washington", 24 April 2002. The original document was posted at www.alneda.com (hosted by Markaz al-Dirasat wal-Buhuth alIslamiyya) and provided to the author by Paul Eedle after the website was shut down.

39. See, for example, James P. Piscatori (ed.), Islam in the Political Process (Cambridge, 1983); Wiktorowicz, The Management of Islamic Activism, ch. 2; and Seyyed Vali Nasr, Islamic Leviathan: State Power and Islam in Malaysia and Pakistan (Oxford, 2001).

40. James P. Piscatori, "Ideological Politics in Sa'udi Arabia", in idem, Islam in the Political Process, pp. 60-6r.

4I. MEMRI, “A New Bin Laden Speech”, Special Dispatch Series, no. 539, I 8 July 2003. 
Al-Qaeda does express some sympathy for sections of the clerical establishment in Saudi Arabia, particularly those who believe in jibad but remain silent out of fear. Bin Laden explains: "The clerics are prisoners and hostages of the tyrants. Some of them told me: "We cannot speak the truth [because we are civil servants] [...]. Many clerics have misled [people] because of threats of beating, imprisonment, or perhaps even death [by the regime]." ${ }^{2}$ Opposing clerics are thus framed as either corrupted tools of the regime or fearful bystanders who hide the truth to protect themselves.

Al-Qaeda further vilifies the reformist scholars by linking them directly to the interests of the enemy: "whether it [the Saudi religious establishment] fulfilled its role intentionally or unintentionally, the harm which eventuated from their efforts is no different from the role of the most ardent enemies of the nation". ${ }^{3}$ This argument is consistently supported by the same verse from the Quran: "O You who believe, do not take the Jews and the Christians as allies. They are allies of each other. If any of you takes them as allies, then he is one of them. Indeed Allah does not guide the wrongdoers" (Quran, al-Ma'idah: 5I).

The corruption of the reformists is contrasted with the character of the jihadis and their scholars. The al-Qaeda fighters are endowed with important characteristics of sacred authority: "dignity, pride, courage, generosity, truthfulness and sacrifice". ${ }^{44} \mathrm{Al}$-Qaeda asserts the character of its supporters in terms of the sacrifice they endure: a willingness to die for the cause demonstrates an unrivaled devotion and love for God and the Muslim community. This sincerity and loyalty to God is emphasized in numerous al-Qaeda statements. Referring to the September I I hijackers, one document stresses that:

The heroes who offered themselves for the destruction of the strongholds of the enemy did not offer themselves in order to gain earthly possessions, or temporary fame, or a transitory desire. Rather, they offered their souls as a sacrifice for the religion of Allah almighty, defending Muslims whom American hands had mistreated by various types of torture and forms of domination and subjugation in every place $[\ldots]$ the only motive these young men had was to defend the religion of Allah, their dignity, and their honor. It was not done as a service to humanity or as an attempt to side with Eastern ideologies opposed to the West. Rather, it was a service to Islam in defense of its people, a pure act of their will, done submissively, not grudgingly. 45

The supporting scholars are framed as "honest" and willing to sacrifice for the cause. Their sincerity is evinced by their oppositional stance and

42. Ibid.

43. Osama Bin Laden, interview with Nida'ul Islam, reproduced in Barry Rubin and Judith Colp Rubin (eds), Anti-American Terrorism and the Middle East (Oxford, 2002), p. I43.

44. Bin Laden, "Declaration of War".

45. Al-Qaeda, "A Statement from Qa'idat al-Jihad". 
consequent imprisonment by Saudi authorities. ${ }^{46}$ These popular intellectuals are exalted as the real ulama, the only ones capable of interpreting Islam free of corruption and revealing the truth to the masses. They are framed as a vanguard capable of interpreting Islam and confronting unIslamic regimes and their scholars of authority:

So $\mathrm{O}$ truthful scholars, reformers and callers to Allah, you are the ones who should be at the front of the lines, to drive the Ummah and to lead the way, for this is incumbent upon your inheritance to the prophethood. Your first duty is the declaration of the truth to the Ummah, and to slap it in the faces of the tyrants without deceit or fear, for this is the requirement of the covenant which Allah had bestowed upon you. The importance of your duty is derived from the danger of the fraudulent and deceiving operations which are being practiced by the scholars of the regimes and the servants of the rulers who deal with the religion of Islam, who have hidden the true state of the Ummah, and who have sold their religion for a cheap offer from this Life. 47

Bin Laden summarizes the intended consequences of the vilification and exaltation strategies:

The fatwa of any official alim [religious figure] has no value for me. History is full of such ulama [clerics] who justify riba [economic interest], who justify the occupation of Palestine by the Jews, who justify the presence of American troops around Harmain Sharifain [the Islamic holy places in Saudi Arabia]. These people support the infidels for their personal gain. The true ulama support the jihad against America. $4^{8}$

\section{Logic}

In part to counter charges of zealotry and selective adherence to radical dogma, al-Qaeda portrays itself as rationally pursuing the will of God through a careful examination of the divine sources and texts. In credentialing itself, al-Qaeda often precedes arguments with qualifying statements intended to emphasize the rationality of the reasoning. Before outlining its theological justification for September I I and the purposeful targeting of civilians, for example, al-Qaeda begins with the following statement:

We pass on this initial report, without details or exposition, regarding the evidence of the legality of this kind of operation. Let it be a quick message to those who dress their political opinions in the garb of a legal ruling. Let it also be a call to those who oppose and condemn the operations to obey Allah, repent, and return to the legal evidence. 49

46. Author's interview with jihadi salafis in Jordan, 1996-1997.

47. Osama Bin Laden, "To the Islamic Ummah, On the First Anniversary of the New American Crusader War”, I2 October 2002. Available at www.jihadunspun.net.

48. Osama Bin Laden interview with Dawn, as reproduced in Rubin and Rubin, Anti-American Terrorism, p. 262.

49. Al-Qaeda, "A Statement from Qa'idat al-Jihad". 
Elsewhere in the document, the movement presents itself as engaged in a scientific and methodical process of legal reasoning to determine what Islamic texts say about the permissibility of operations such as September I I:

We should never think little of the passing of souls, especially the Muslims among them. And this is what compels us to pay attention to the issue of legal evidence from all its angles, without privileging one side over another and without ignoring one matter on account of another. After study and deliberation, we have found that operations like this are what will return its glory to the ummah and convince the oppressive enemy of the rights of the Islamic community. ${ }^{50}$

The language is emotionally detached, as though its architects are neutral, scientific observers merely seeking data and truth through unbiased research and observations that allow for the possibility of alternative conclusions.

At the same time, al-Qaeda tries to decredential its adversaries by challenging the logic of alternative theological arguments. First, it emphasizes inconsistencies in the reformist legal rulings to call into question the basis and process of judgment. Specifically, the frame draws on the broad support for "martyrdom" operations (suicide bombings) in the Palestinian territories and argues that a consistent argument leads to the inevitable conclusion that such operations are permissible in the US as well. Several reformists have lent their support to Palestinian suicide bombings while decrying September I I as heretical and illegal according to religious principles. Al-Qaeda argues that the legal basis for "martyrdom" operations against Israel and the US are one and the same and that the reformists are hypocrites:

First of all, America's status among Muslims is the same as that of the Jews - they are both people of war. What is permissible regarding the right of the occupying enemy to the land of Palestine permits the right of anything like it [...]. If you are surprised by this, you will truly be surprised by those who rule that the martyrdom operations in Palestine in which civilians fall victim are among the highest forms of jihad, and then rule that the martyrdom operations in America are wrong because of civilian deaths. This inconsistency is very strange! How can one permit the killing of the branch and not permit the killing of the supporting trunk? All who permit martyrdom operations against the Jews in Palestine must allow them in America. If not, the inconsistency leads to nothing but a type of game playing with the legal ruling. ${ }^{\mathrm{I}}$

Since September I I, another common decredentialing tactic is to portray reformists as inspired by emotion, rather than logic. Immediately after the 
attacks, Hammoud Al-Uqlaa Ash-Shuaybi [d. 2002], a radical Saudi cleric of some standing, issued a widely circulated fatwa supporting the alQaeda operation. Although al-Uqlaa was not a formal member of the movement, his fatwa was quickly adopted and supported by al-Qaeda. ${ }^{52}$ He prefaces his argument with the following statement:

[...] it is unfortunate and disturbing to see that a lot of fellow scholars have preferred the side of mercy and emotion and forgotten and ignored what that Kufr Nation (America) is doing such as killing, destroying and spoiling most of the Muslim lands, and showing no mercy or kindness in that. Consequently, I find it incumbent upon me to refute some false claims and misconceptions that some fellow scholars are relying upon in trying to support their positions. 53

About seven months later, al-Qaeda made the same argument in its justification for September i I:

Despite the clarity of the matter and the obvious nature of the evidence [...] it is regrettable that many of the motives [of the "martyrs"] were destroyed in the comforting of America, the expressions of sorrow for her, and the legal rulings to assist her and to donate blood for her innocent [!!] victims. ${ }^{54}$

\section{CONCLUSION}

Social movements are about persuasion. Whether constituted by identitycentered aspirations of postmaterialist collective transformation and shared networks of meaning, or more narrow material interests, movements must convince targets of activism that change is necessary. As this volume notes, popular intellectuals are inextricably involved in persuasion attempts through frames and framing processes, whether directly or indirectly; and the potential for frame resonance hinges, in part, on their credibility. As a result, framing strategies include attempts to emphasize the credibility of ingroup intellectuals while discrediting rivals.

The purpose of this article is mostly taxonomic. It identifies four framing strategies relevant to the credibility of popular intellectuals, particularly in the context of framing contests: vilification, exaltation, credentialing, and decredentialing. Although the criteria of credibility vary according to movement, issue, and context, movements generally use these strategies to credit and discredit popular intellectuals by assessing knowledge, character, and logic. The goal is to promote positive attributes for ingroup intellectuals and negative connotations for competitors, thus

52. Al-Qaeda Statement, October I3, 200I, reproduced in Rubin and Rubin, Anti-American Terrorism, p. 254.

53. Hammoud Al-Uqlaa Ash-Shuaybi, "Fatwa on Events Following i I September 200I", no date. Originally accessed at www.azzam.com in October 200I. The website was shut down sometime in 2002.

54. Al-Qaeda, "A Statement from Qa'idat al-Jihad". 
asserting the group's authority to speak on behalf of an issue or constituency.

In the case of al-Qaeda, the fragmentation of sacred authority in the Muslim world means that the movement must pay special attention to credibility. The complexity of religious debates over the permissibility of violence in Islam places religious scholars at the heart of contests over meaning - they are responsible for interpreting Islam on behalf of the community. Al-Qaeda portrays scholars who support its jibad as logical, religious experts of good repute while characterizing opposing clerical popular intellectuals as emotional, corrupt, naïve, and ill-informed about politics. Framing strategies are intended to support al-Qaeda's call for jihad by asserting its sacred authority at the expense of reformist Islamic scholars.

Although more research is needed, the case study suggests a causal argument about the relationship between popular intellectuals and frame resonance: varying degrees of resonance can be explained by the ability of a movement to direct framing strategies toward accepted criteria of authority used by target audiences in a given context to evaluate the reliability of frames. That is, framing strategies and how they align with established criteria of authority are variables that might explain differential degrees of frame resonance. One could plausibly argue, for example, that part of al-Qaeda's popularity, even among those unwilling to participate in violence themselves, is its focus on vilification, which taps into widespread concerns about the character of the Saudi clerical establishment and its ability to issue independent religious rulings. The next step is to test such propositions empirically, preferably using both positive and negative cases (frame successes and frame failures) to thwart problems of circularity. 55 Studies along these lines are difficult, since researchers need access to individuals who support groups like al-Qaeda, as well as those who were exposed to the message and rejected the jib adis, but such research promises to explain better the causal connection between the reputation of popular intellectuals and frame resonance.

55. Robert D. Benford, “An Insider's Critique of the Social Movement Framing Perspective”, Sociological Inquiry, 67 (1997), pp. 4I I-4I 2. 